\title{
Larotrectinib: A Novel Tumor-Agnostic Neurotrophic Tropomyosin Receptor Kinase (NTRK) Inhibitor in Advanced Solid Tumors
}

\author{
Manikandan Dhanushkodi ${ }^{1} \quad$ Jyoti Bajpai \\ ${ }^{1}$ Department of Medical Oncology, Cancer Institute (WIA), Chennai, \\ Tamil Nadu, India \\ 2Department of Medical Oncology, Tata Memorial Hospital, \\ Mumbai, Maharashtra, India \\ Ind J Med Paediatr Oncol 2021;42:279-281.
}

\begin{abstract}
Address for correspondence Manikandan Dhanushkodi, MD, DM, DNB, Department of Medical Oncology, Cancer Institute (WIA), Chennai, 38, Sardar Patel Road, Chennai 600036, Tamil Nadu, India (e-mail: dmani1982@gmail.com).
\end{abstract}

\begin{abstract}
Keywords

- larotrectinib

- NTRK inhibitor

- tumor agnostic therapy

Larotrectinib and entrectinib are highly selective, potent tropomyosin receptor kinase fusion inhibitors. It is U.S. Food and Drug Administration approved for the treatment of adult and pediatric advanced solid tumors with neurotrophic tropomyosin receptor kinase fusion genes who are refractory to standard systemic therapy. The response rate was $\sim 80 \%$ and was rapid and durable. The median progression-free survival was 28 months. The side effects include anemia, weight gain, hepatotoxicity, and neuropsychiatric manifestations. Phase 3 , randomized controlled trials are warranted to assess survival benefit.
\end{abstract}

\section{Introduction}

Neurotrophic tropomyosin receptor kinase (NTRK) fusions occur in low incidence $(<1 \%)$ in common tumors and high frequency in rare tumors like secretory breast cancer, deficient mismatch repair colorectal cancer, and infantile fibrosarcoma (-Table 1). ${ }^{1}$ NTRK fusions are mutually exclusive as compared with other pathogenic driver mutations. NTRK fusion causes ligand-independent downstream cell signaling and survival. ${ }^{2}$ Patients with NTRK fusions are usually refractory to standard systemic therapy. NTRK fusion inhibitors have shown to be promising in this subset of patients.

\section{Discovery}

Larotrectinib was developed by Array Biopharma (Boulder, Colorado, United States) and licensed to Loxo Oncology in 2013. It was initially awarded orphan drug status in 2015 for patients with advanced soft tissue sarcoma.

\section{Mechanism of Action}

Larotrectinib is a highly selective, potent, adenosine triphosphate competitive, tyrosine receptor kinase (TRK) inhibitor that targets the family of proteins inclusive of TRKA, TRKB, TRKC that are encoded by NTRK1, NTRK2, and NTRK3 genes, respectively.

\section{Pharmacokinetics}

The bioavailability of larotrectinib is $34 \%$. It is metabolized primarily by CYP3A4. It is excreted $58 \%$ in feces and $39 \%$ in urine. The mean clearance is $98 \mathrm{~L} / \mathrm{h}$ with a half-life of 2.9 hours.

\section{TRK Fusion Testing}

TRK fusion testing can be done by immunohistochemistry, fluorescent in situ hybridization (FISH), reverse-transcriptase-polymerase chain reaction (RT-PCR),
DOI https://doi.org/ $10.1055 / \mathrm{s}-0041-1732823$ ISSN 0971-5851
(C) 2021. Indian Society of Medical and Paediatric Oncology. This is an open access article published by Thieme under the terms of the Creative Commons Attribution-NonDerivative-NonCommercial-License, permitting copying and reproduction so long as the original work is given appropriate credit. Contents may not be used for commercial purposes, or adapted, remixed, transformed or built upon. (https://creativecommons.org/licenses/by-nc-nd/4.0/). Thieme Medical and Scientific Publishers Private Ltd. A-12, Second Floor, Sector -2, NOIDA -201301, India 
or DNA/RNA based next-generation sequencing. ${ }^{3}$ European Society of Medical Oncology recommends FISH or RT-PCR for NTRK gene in patients with histology known to harbor highly recurrent NRTK rearrangements and sequencing/immunohistochemistry otherwise. ${ }^{4}$

\section{Approval Status}

In November 2018, larotrectinib was U.S. Food and Drug Administration (FDA) approved for adult and pediatric patients with metastatic solid tumors with NTRK gene fusion without a known acquired resistance mutation who have no standard treatment option. ${ }^{5}$ The landmark trials that led to the FDA approval of larotrectinib are shown in - Table 2. Larotrectinib is currently not approved by Drugs Controller General of India.

\section{Recommended Dose}

Adults: Capsule larotrectinib $100 \mathrm{mg}$ twice daily (BD) (with or without food) until progression

Pediatrics (1 month to 18 years): Capsule larotrectinib $100 \mathrm{mg} / \mathrm{m}^{2} \mathrm{BD}$ (with or without food, maximum $200 \mathrm{mg} /$ day) until progression

Table 1 Prevalence of NTRK fusion-positive cancers

\begin{tabular}{|l|l|}
\hline Tumor type & Prevalence, $\boldsymbol{n}$ (\%) \\
\hline Secretory breast cancer & $12 / 13(92)$ \\
\hline $\begin{array}{l}\text { Colorectal cancer (defi- } \\
\text { cient mismatch repair) }\end{array}$ & $10 / 13(77)$ \\
\hline $\begin{array}{l}\text { Mammary analogue secre- } \\
\text { tory carcinoma }\end{array}$ & $2 / 3(66)$ \\
\hline Infantile fibrosarcoma & $2 / 4(50)$ \\
\hline $\begin{array}{l}\text { Pediatric high-grade } \\
\text { glioma }\end{array}$ & $28 / 127(22)$ \\
\hline Spitzoid melanoma & $23 / 140(16)$ \\
\hline Papillary thyroid carcinoma & $4 / 33(12)$ \\
\hline Colorectal cancer & $13 / 346(4)$ \\
\hline Cholangiocarcinoma & $1 / 28(4)$ \\
\hline Lung adenocarcinoma & $3 / 91(3.3)$ \\
\hline Glioblastoma & $3 / 115(3)$ \\
\hline
\end{tabular}

Abbreviation: NTRK, neurotrophic tropomyosin receptor kinase.

\section{Efficacy}

The objective response rate was $79 \%$ with a complete response in $16 \%$. Among the responders, the median duration of response was 35 months. The median progression-free survival (PFS) was 28 months with a 12-month PFS rate of $67 \%$. The median overall survival (OS) was 44 months with an estimated 12 -month OS of $88 \%$ (- Table 2). ${ }^{6}$

\section{Strength and Formulation}

Larotrectinib is available in $25 \mathrm{mg}$ capsule, $100 \mathrm{mg}$ capsule, and $20 \mathrm{mg} / \mathrm{mL}$ solution.

\section{Toxicity}

The grade 3 toxicities include anemia (11\%), weight gain (7\%), neutropenia (7\%), and increased aspartate/alanine transaminase (7\%). ${ }^{7}$ Neurologic and psychiatric manifestations can occur.

\section{Dose Modifications}

For any adverse event $\geq$ grade 3 , larotrectinib needs to be stopped until grade 1 and restarted at a lower dose as per recommendation. The 1 st dose modification is $75 \mathrm{mg} \mathrm{BD}$, 2nd dose modification is $50 \mathrm{mg} \mathrm{BD}$, and 3rd dose modification is $25 \mathrm{mg}$ BD.

\section{Other NTRK Inhibitor}

Entrectinib: In August 2019, FDA approved entrectinib for adult and pediatric ( $\geq 12$ years) patients with metastatic solid tumors with NTRK gene fusion without a known acquired resistance mutation who have no standard treatment option. Entrectinib is also approved for adults with ROS1-positive metastatic nonsmall cell lung cancer. The recommended dose is $600 \mathrm{mg} /$ day.

\section{Resistance}

The resistance can occur due to kinase domain mutations in the NTRK gene. Second-generation NTRK inhibitors like Loxo-195 and repotrectinib are under development to overcome this resistance. ${ }^{8}$

Table 2 Landmark trials with larotrectinib

\begin{tabular}{|c|c|c|c|c|c|}
\hline Author & Phase & Sample size & Inclusion criteria & Response (\%) & PFS \\
\hline Drilon et al ${ }^{8}$ & $1 / 2$ & 55 & $\begin{array}{l}\text { Salivary gland tumor (22\%) } \\
\text { Infantile fibrosarcoma (13\%) } \\
\text { Other soft-tissue sarcomas (20\%) }\end{array}$ & 75 & $\begin{array}{l}\text { Not reached } \\
\text { (range: } 0.7-26 \text { months) } \\
\text { 1-year PFS: } 55 \%\end{array}$ \\
\hline Laetsch et al $^{9}$ & $1 / 2$ & 17 & $\begin{array}{l}\text { Infantile fibrosarcoma (33\%) } \\
\text { Other soft-tissue sarcomas (29\%) } \\
\text { Papillary thyroid cancer }(8 \%)\end{array}$ & 93 & - \\
\hline Hong et $\mathrm{al}^{10}$ & 1 & 8 & Adults with TRK fusion genes & 100 & - \\
\hline Hong et al ${ }^{6}$ & $\begin{array}{l}\text { Pooled } \\
\text { analysis }\end{array}$ & 159 & $\begin{array}{l}\text { Adults and pediatric patients with } \\
\text { TRK fusion genes }\end{array}$ & 79 & - \\
\hline
\end{tabular}

Abbreviations: TRK, tropomyosin receptor kinase; PFS, progression-free survival. 


\section{Cost-Effectiveness}

United Kingdom's National Institute for Health and Care Excellence guidelines mention that larotrectinib is not cost-effective for its use as a tumor agnostic therapy.

\section{Take-Home Points}

- Larotrectinib and entrectinib are highly selective, potent TRK fusion inhibitors in adult and pediatric advanced solid tumors refractory to standard systemic therapy.

- The response rate is $\sim 80 \%$ and is rapid and durable.

- The side effects include anemia, weight gain, hepatoxicity, and neuropsychiatric manifestation.

- Phase 3, randomized controlled trial with NTRK inhibitors to assess survival benefit is warranted.

\section{Conflict of Interest}

None.

\section{References}

1 Lassen U. How I treat NTRK gene fusion-positive cancers. ESMO Open 2019;4(Suppl 2):e000612
2 Jørgensen JT. A paradigm shift in biomarker guided oncology drug development. Ann Transl Med 2019;7(7):148

3 Penault-Llorca F, Rudzinski ER, Sepulveda AR. Testing algorithm for identification of patients with TRK fusion cancer. J Clin Pathol 2019;72(7):460-467

4 Marchiò C, Scaltriti M, Ladanyi M, et al. ESMO recommendations on the standard methods to detect NTRK fusions in daily practice and clinical research. Ann Oncol 2019;30(9):1417-1427

5 Scott LJ. Larotrectinib: first global approval. Drugs 2019;79(2):201-206

6 Hong DS, DuBois SG, Kummar S, et al. Larotrectinib in patients with TRK fusion-positive solid tumours: a pooled analysis of three phase $1 / 2$ clinical trials. Lancet Oncol 2020;21(4):531-540

7 Drilon A, Laetsch TW, Kummar S, et al. Efficacy of larotrectinib in TRK fusion-positive cancers in adults and children. $\mathrm{N}$ Engl J Med 2018;378(8):731-739

8 Drilon A, Ou SI, Cho BC, et al. Repotrectinib (TPX-0005) is a next-generation ROS1/TRK/ALK inhibitor that potently inhibits ROS1/TRK/ALK solvent- front mutations. Cancer Discov 2018;8(10):1227-1236

9 Laetsch TW, DuBois SG, Mascarenhas L, et al. Larotrectinib for paediatric solid tumours harbouring NTRK gene fusions: phase 1 results from a multicentre, open-label, phase $1 / 2$ study. Lancet Oncol 2018;19(5):705-714

10 Hong DS, Bauer TM, Lee JJ, et al. Larotrectinib in adult patients with solid tumours: a multi-centre, open-label, phase I dose-escalation study. Ann Oncol 2019;30(2):325-331 